\title{
Extending Health Expectancy
}

\author{
G. Terry Sharrer ${ }^{1}$
}

\begin{abstract}
All health-related issues exist in a context of extending health expectancy. Behavioral risk factors, diagnostic "omics," disparities, insurance, tissue engineering, and climate can shorten life expectancy, but before that, health expectancy. Longer life can bring decades of disability; longer health can mean dying healthy after brief incapacity. Because health precedes other accomplishments, extending average health expectancy into the ninth decade during the $21^{\text {st }}$ century would have an impact comparable to doubling life expectancy in the $20^{\text {th }}$ century.
\end{abstract}

Keywords: Personalized Health; Risk Factors; Poverty; Artificial Intelligence; Climate Change; Microbiome; Telemedicine; Old Age.

She was a medical doctor (some say), a beauty with a diamond set in a front tooth, a gold miner and hotel operator in the Klondike, and she had the magic remedy for lifelong health. Luella "Diamond Lil" Day McConnell (b. Baltimore, MD, 1870-d. Island Grove, FL, 1927) owned the "Fountain of Youth" in St. Augustine, FL that Juan Ponce de Leon never found. Actually, he wasn't looking for it; later Spanish explorers made up that story, though it played on a legend that the father of history, Herodotus, recorded in ancient times. Be that as it may, Diamond Lil knew youth and health went hand in hand, and she made youth accessible at her fountain with an admission charge and a ten cent glass of water. She may have been a quack, but certainly ahead of her time, perhaps even a pioneer in the mass culture of rejuvenation. ${ }^{1}$

All societies can see in nature youth's attractions, but western countries appear to celebrate healthful youth more than Asian cultures. Commercialism could explain this.

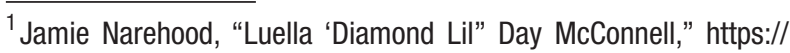
www.westcotthouse.com/things-to-do-in-st-augustine/luelladiamond-lil-day-mcconnell-10; Courtney S. Warren, "The Mass Media, Body Image, and Self-Deception," https://www.psychology today.com/us/blog/naked-truth/201406/the-mass-media-bodyimage-and-self-deception
}

Millennials and Gen Zers typically have less wealth than their parents' generation, but targeted advertising accesses younger spenders who are vulnerable to suggestions of being "the worried well." Dr. Sidney Garfield, co-founder with Henry J. Kaiser of the first health maintenance organization, KaiserPermanente, coined this term in a 1970 Scientific American article to describe industrial workers who were at risk for injury, but not really sick. Over time, the worried well extended to people who, through their own health insecurities - whether from family history, general anxiety from advertising or noticeable aging - became obsessed with their health. A more recent term is "cyberchodria," according to the Macmillan Dictionary, means a mistaken belief about illness based on an interpretation of symptoms from an internet search. ${ }^{2}$

For all its new tools to do "personalized health," the $21^{\text {st }}$ century has a high hill to climb to equal the $20^{\text {th }}$ century's greatest achievement - an increase in life expectancy from 49 to 77 years. Surprisingly, there is not widespread agreement about how this happened — or more specifically, whether public health or medicine was chiefly responsible.

\footnotetext{
2 "Worried well" and "cyberchondria" from the Macmillan Dictionary, https://www.macmillandictionary.com/us/buzzword/entries/ worried-well.html
}

${ }^{1}$ Editor, Medical Automation.org's weekly newsletter of innovation. Curator of Health Sciences (Ret.) Smithsonian Institution, Washington, DC, USA. Published online 30 September 2019; doi:10.1142/S252973251940011X

This is an Open Access article published by World Scientific Publishing Company. It is distributed under the terms of the Creative Commons Attribution 4.0 (CC BY) License which permits use, distribution and reproduction in any medium, provided the original work is properly cited. 
But before the most prominent actors - penicillin and polio immunization - came on stage, life expectancy was already rising. The homely window screen, which became common architectural amenities in the late $19^{\text {th }}$ century, helped knock down mosquito-borne malaria and yellow fever, and the sixtyfive diseases (e.g. typhoid, cholera, dysentery, conjunctivitis, tuberculosis) flies carried. Milk pasteurization - originally, 106 degrees for 15-20 seconds - killed the germs responsible for salmonella, diphtheria, hepatitis, among others and saved masses of children from early graves. Health campaigns against spitting in the street, and accumulated garbage and horse manure, and in favor of chlorinated city water and sanitary facilities in schools added survival advantages. And, it was easier to teach children to wash their hands before eating, than indoctrinating surgeons to scrub up. ${ }^{3}$

World War II marked a turning point, as national emergencies often do. In the first instance, the war ended the Great Depression, and people had more income to spend on higher quality food and newer housing. Penicillin dated from Alexander Fleming's experiments in the late 1920's, but the U.S. Department of Agriculture's Northern Research Laboratory in Peoria, IL developed the means for large scale culturing, and just in time for the Allies invasion of Normandy in June, 1944. Albert Schatz, at the New Jersey Agricultural Experiment Station, discovered the Streptomyces organism that he and Selman Waksman purified into streptomycin — the first effective drug against "the white plague," tuberculosis. Agronomists all around the world soon collected soil samples for other antibiotics. Drs. Thomas Francis and Jonas Salk had been working on a possible vaccine for influenza in case the 1918-1919 Great Pandemic returned after the Second World War, but when that threat passed, they turned to a killed virus preparation for poliomyelitis. A few years later, Dr. Albert Sabin developed the live-attenuated oral polio vaccine. It is now almost past living memory when parents lined up in droves to have their children immunized rather than risking confinement to an "iron lung," if not death. ${ }^{4}$

Total success against infectious human diseases happened only once, so far. In 1980, the World Health Organization declared that smallpox was completely eradicated. This

\footnotetext{
${ }^{3}$ Glessner House, "A Brief History of the Humble Widow Screen," https://www.glessnerhouse.org/story-of-a-house/2016/8/28/abrief-history-of-the-humble-window-screen; Laura Helmuth, "Why Are You Not Dead Yet?:" https://slate.com/technology/2013/09/ life-expectancy-history-public-health-and-medical-advances-thatlead-to-long-lives.html

${ }^{4}$ Roy Porter, The Greatest Benefit to Mankind: A Medical History of Humanity (New York: W. W. Norton \& Company, 1997), pp. 454-461; Hilary Koprowski and Michael B. A. Oldstone, Microbe Hunters Then and Now (Bloomington, IL: Medi-Ed Press, 1996), passim by disease.
}

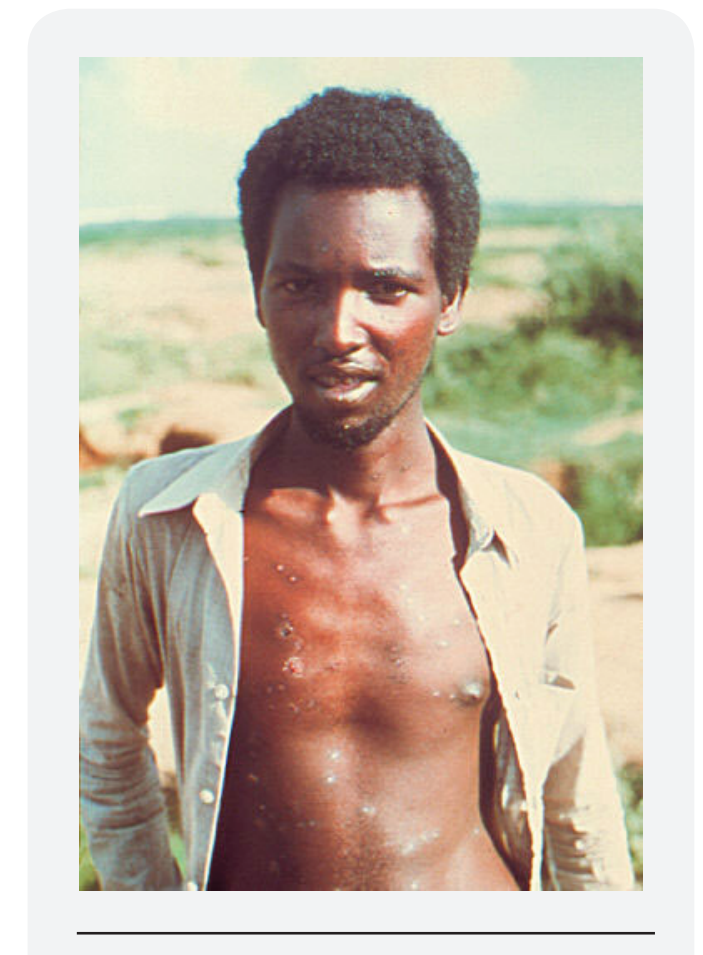

Figure 1. Ali Maolin, 1977, the last wild type smallpox case on Earth, foretelling the global eradication of a disease that once killed half of all human children before age 5. Source: Dr. D. A. Henderson.

one affliction, from an animal virus that mutated to infect people, killed half of the world's children who died under the age of 5 from antiquity until the $20^{\text {th }}$ century. Lillian Barber, age 43 in 1949, was the last person in the US to die from a final outbreak in Texas. Vaccinations of military personnel in both world wars reduced the vulnerable population, and in 1966, Dr. Donald A. Henderson, with the Centers for Disease Control, headed the World's Health Organization's Smallpox Eradication Campaign which ran down the last "wild type" case in Somalia in 1977. Three years later, the disease reached the end of its history, though frozen samples of the virus remained in suspended animation with the US and Russian militaries (Fig. 1). ${ }^{5}$

Coincidentally, the end of smallpox and the beginning of AIDS overlapped in 1980. The viruses responsible for immune suppression allowed opportunistic pathogens, like Pneumocystis carinii (pneumonia), to actually kill people. By 1989, 145 countries reported a total of 142,000 AIDS cases, and ten years later, the World Health Organization listed AIDS as the

\footnotetext{
5 "Lessons from the eradication of smallpox: an interview with D. A. Henderson," (2013), https://www.ncbi.nlm.nih.gov/pmc/ articles/PMC3720050/ ; "Last U.S. Smallpox Outbreak left Mental Scars on Witnesses," https://www.latimes.com/archives/la-xpm2001-dec-26-mn-18048-story.html
} 
fourth greatest cause of death from infectious diseases fourteen million dead, and thirty-three million more living with the virus. While it once seemed like AIDS could become the first disease to threaten humanity's survival, the development of anti-retroviral drugs, beginning with azidothimidine (AZT) in 1985 and some two dozen others by 2010 gradually suppressed AIDS mortality while allowing more people to survive with the virus. In 2016, 15,807 Americans who had been diagnosed with AIDS died, while 1,008,929 remained alive with drug treatment. ${ }^{6}$

To some extent, the fall of infectious disease mortality unmasked the big killers that stalked the $20^{\text {th }}$ century cardiovascular disease, myocardial infarctions, and neoplasms - aka: stroke, heart attack and cancer. People had to live long enough to suffer from these diseases that typically struck in the fourth to sixth decade of life. Only two US Presidents have died from cancer - Grant (throat) and Jefferson (probable prostate). Two dozen died from cardiovascular failure, and one each from Alzheimer's disease (Reagan) and vascular Parkinson's (George H. W. Bush). Both Presidents Franklin Roosevelt and Dwight Eisenhower had surgery for melanomas, but Roosevelt died of a cerebral hemorrhage (age 63) and Eisenhower, of congestive heart failure (age 68). Their clinical histories illustrated what was killed most Americans prematurely.

Franklin Roosevelt was 39 years old in 1921 - then working as an investment banker after being on the losing second slot of the 1920 Presidential election - when he suffered paralysis in both legs, then thought to be polio, but later questioned as Guillain-Barre Syndrome. Making light of his affliction, he went on to win four terms as President. The first sign of chronic hypertension presented in 1937, and again in 1944 when his blood pressure registered 186/108 mm Hg. Just before the his Yalta meeting with Churchill and Stalin, his number was 260/150 $\mathrm{mm} \mathrm{Hg}$, and earlier on the day he died, April 12, 1945, it reached 300/190. At that time, hypertension did not figure prominently in health assessments, apart from

\footnotetext{
6 "History of HIV and AIDS Overview," https://www.avert.org/professionals/history-hiv-aids/overview; Centers for Disease Control and Prevention, "HIV in the United States and Dependent Areas," https:// www.cdc.gov/hiv/statistics/overview/ataglance.html; Many HIV-infected persons died of pneumonia, but even without HIV, pneumonia takes a heavy toll. The CDC\&P lists pneumonia as the single largest infectious disease of children under the age of 5 who die, worldwide. Together with the Wellcome Sanger Institute and Emory University, the CDC\&P is conducting the Global Pneumococcal Sequencing Project, which so far has identified 621 strains of Streptococcus pneumoniae in fifty countries: https://www.technologynetworks.com/ genomics/news/pneumonia-mapped-in-global-genomic-survey-ofdisease-causing-bacterium-320499
}

normal aging. He only came up short for average white male life expectancy (63.6 years) by three months. ${ }^{7}$

Both Eisenhower and Roosevelt were heavy smokers: Roosevelt, 2 packs a day until he died, Eisenhower, 4 packs a day until he stopped in 1949. Smoking deprives tissue of oxygen; so, there's no telling its full impact; neither man was healthy, though they tried to have the pubic see them as the picture of health. Eisenhower had elevated blood pressure during World War II, but shortly before his 1956 Presidential campaign, it rose to the high end of normal, $140 / 100 \mathrm{~mm}$ $\mathrm{Hg}$, and he had a mild myocardial infarction. Dr. Paul Dudley White told him he could continue the campaign if he took it easy and followed a low fat diet. It is not known whether it was the President or his cooks who substituted salt for fat to improve flavor, without knowing if he had salt sensitive hypertension. Then, in September 1957, Eisenhower had a stroke, just before the Soviets launched "Sputnik" and Americans seriously feared ICBM's armed with $\mathrm{H}$-bombs raining down. To keep the nation calm, White House officials suppressed news of the stroke, though that only led to reporters hinting the President was becoming senile. He survived his second term, ending in 1960, but between then and his death on March 28, 1969, the former President suffered six more heart attacks and 14 cardiac arrests. When he had his gall bladder removed in 1966, the surgeons found six cholesterol "stones," which likely contributed to his failing health, though at age 78 , he had survived 11 years and six months longer than average white male life expectancy in $1969 .^{8}$

President Eisenhower's autopsy in 1969 showed, in one individual, conditions that prevailed in millions of other cases: "coronary atherosclerotic occlusive disease, multifocal, severe, with multiple thrombi." Both coronary arteries had hardened with calcification, but the left anterior (front) descending artery — the vessel cardiologists nicknamed "the widow-maker" - had almost no blood passing through it, and its posterior branch was completely blocked. Because of earlier infarctions, his heart muscle presented "a very scarred myocardium with extensive areas of calcification throughout the wall of the left ventricle and septum and a laminated, partly calcified clot about the size of a Ping-Pong ball occupying the apex [i.e. lower end] of the left ventricle." Additionally, the pathologist found an aneurysm (dilation) in the front left

\footnotetext{
${ }^{7}$ Armando Susman, "Franklin Roosevelt's Last Illness," Hektoen International, A Journal of Medical Humanities, https://hekint. org/2017/01/31/franklin-delano-roosevelts-last-illness/

${ }^{8}$ A. Kucharski, "Medical Management of Political Patients: the Case of Dwight D. Eisenhower," Perspectives in Biology \& Medicine 22 (1978): 115-126; Franz H. Messerli, Adrian W. Messerli, and Thomas F. Luscher, "Eisenhower's Billion-Dollar Heart Attack - 50 Years Later," New England Journal of Medicine 353 (September 22, 2005): 1205-1207.
} 
ventricle near the apex, with a multilayered clot attached to it. In the end, his heart had become so weakened that it simply could not pump sufficient blood to keep him alive; death came from congestive heart failure. ${ }^{9}$

Eisenhower's long and slow heart failure was a slightly different kind of coronary heart disease (CHD) that suddenly killed a third of all Americans in the 1960s, and was the leading cause of death worldwide. It afflicted men most heavily, and the image of a middle-aged man, in seemingly good health, grabbing his chest and falling down dead became a fright as a bloody cough or swollen lymph nodes (buboes, from which, bubonic plague is named) had been in earlier times. However, in 1974, a Los Angeles, CA cardiologist, Weldon Walker, may have been first to recognize that coronary disease mortality had been falling for about a decade. Others doubted this at first; then, supporting analysis concluded that between 1968 and 1978, deaths from heart attacks had declined by $20 \%$, and showed no sign of slowing though epidemiologists broadly could not agree whether prevention or treatment accounted the most for this astonishingly good news. ${ }^{10}$

Both sides could self-acclaim. Medicine listed its contributions: the heart lung machine (1951), thiazide diuretics for hypertension (1958), a totally implantable pacemaker (1958), cardiac care units (1960), coronary artery bypass surgery (1961), defibrillation (1962), and heart transplantation (1967), among others. For survivors of heart attacks this worked out to fewer days in the hospital, more chemistry tests, X-rays, and electrocardiograms. But these advances also meant a patient could live on for subsequent myocardial infarctions. ${ }^{11}$

For their part, public health authorities could point to several epidemiological investigations that began to tease out the strategies for preventing heart attacks in the first place. First among these was the "mother" of cardiac health research, the Framingham Heart Study (1948-present). It enrolled 5,209 residents of Framingham, MA, between the ages of 30 and 82 with no prior history of heart disease, and aimed to identify the incidence of arteriosclerotic (narrowing of arteries) and atherosclerotic (arterial clogging) hypertension. The study has continued to follow the original cohort's children and grandchildren. Because the participants had no previous heart conditions, the study documented over two

\footnotetext{
${ }^{9}$ Clarence G. Lasby, Eisenhower's Heart Attack: How Ike Beat Heart Disease and Held on to the Presidency (Lawrence: University Press of Kansas, 1997), pp. 321-322.

${ }^{10}$ David S. Jones and Jeremy A. Greene, "The Decline and Rise of Coronary Heart Disease: Understanding Public Health Catastrophism," American Journal of Public Health, July 2013 (103: 7), pp. 1207-1218.

${ }^{11}$ W. Bruce Fye, American Cardiology: The History of a Specialty and its College (Baltimore: The Johns Hopkins University Press, 1996), p. 255.
}

decades the effects of smoking, obesity, hypertension, levels of high and low density cholesterol, exercise, social factors (e.g. Ioneliness), heredity, and heart physiology. ${ }^{12}$

Framingham's researchers first focused on hypertension, little knowing how difficult or how long it would take to turn research findings into actionable clinical practice. Every physician knew that blood pressure was measured in two numbers - systolic and diastolic — say $120 / 70 \mathrm{~mm} \mathrm{Hg}$. The systolic or first number represented the arterial pressure during a beat; diastolic meant the pressure between beats. This is how fifty million gallons of blood, over a lifetime, is pumped through 100,000 miles of arteries, arterioles, capillaries, venules and veins of the circulatory system, with arterial elasticity keeping blood flowing when the heart itself relaxes. Until the 1970's, medical schools and their standard texts emphasized the diastolic number as the best indicator of cardiovascular health, paying comparatively little attention to the systolic. The same too for labile hypertension (i.e. highly varying numbers, even during a single day) was thought to be unimportant. But the Framingham researchers gradually eroded these earlier assumptions, and by the late 1980s, systolic blood pressure was accepted as the best indicator of heart function, and labile variations became linked to different "risk factors." At first, so many risk factors presented that determining a practical scale was a problem; so, scoring reduced to seven values: age, total cholesterol, weight, ECG abnormality, hemoglobin, cigarettes smoked, and systolic blood pressure. With those standards, physicians could calculate low, intermediate and high risk for developing heart disease in the next ten years. Reaching that point took a half century. ${ }^{13}$

\footnotetext{
${ }^{12}$ Syed S. Mahmood, Daniel Levy, Ramachandran S. Vasan, and Thomas J. Wang, "The Framingham Heart Study and the Epidemiology of Cardiovascular Diseases: A Historical Perspective," Lancet, 2014 Mar 15; 383(9921): 999-1008 and online: https://www.ncbi. nlm.nih.gov/pmc/articles/PMC4159698/

${ }^{13}$ Arthur C. Guyton and John E. Hall, Textbook of Medical Physiology (Philadelphia:W. B. Saunders Company, 1996, 9th edition), p. 275 and Chapter 14., Mahmood, et al, "The Framingham Heart Study. . ..," https://www.ncbi.nlm.nih.gov/pmc/articles/PMC4159698/; In routine physical examinations, the physician may take a closer reading of the heartbeat, feeling both sides of the neck (catrotid arteries), underarms (axillary arteries), writs (radial arteries), groin (femorial arteries), knees (popliteal arteries), ankles (posterior tibial arteries), and feet (dorsalis pedis arteries). Each point indicates the state of circulation in that region. With a stethoscope, a doctor can hear if the arterial pulse is "slapping" and quickly falling off (called a "waterhammer" or collapsing pulse); or when a pistol-shot sound (called Traube's sign) emits from the femoral pulse. If slight finger pressure has difficulty compressing an artery, and senses a forced strike (called a "hard pulse"), the physician might assume a hypertension condition, if the nurse had not already established that with a sphygmomanometer (blood-pressure cuff) reading.
} 
Before Framingham, many medical experts doubted that smoking damaged the cardiovascular system. And cigarette companies agreed. In a survey of 113,597 physicians, the R. J. Reynolds Tobacco Company famously advertised that "More Doctors Smoke Camels Than Any Other Cigarette." Eventually, though, investigators linked chemicals in tobacco smoke to fibrosis, lipid deposition, and calcification in the vascular system. Epidemiological studies also showed that the risk of death from atherosclerosis had a direct relationship with the number of cigarettes smokers consumed daily. Similarly, epidemiological evidence linked diabetes to atherosclerosis, as sugar in the blood attached to low density lipoproteins and accelerated atherogenesis. ${ }^{14}$

Because arterial plaques contained lipoproteins, the Framingham researchers noted dietary fat as a risk factor long before Michael Brown and Joseph Goldstein published their landmark findings about cholesterol in 1973. Many cells in the body, but principally those of the liver, intestines, sex organs, and adrenal glands, synthesize cholesterol from lipids and an alcohol, and use it in the structure of their permeable membranes. Cholesterol circulating in the blood stream also converts to several hormones - testosterone, estrogen, cortisone and aldactone - and to bile acids.

In both cholecystitis and atherosclerosis, the low-density lipoproteins that transport cholesterol through the blood stream and to all tissues of the body are the initiating agents of disease. Differing protein components of the lipoproteins, not different cholesterols, determine molecular sizes and densities. Total cholesterol may be low, but if small, low and high density lipoproteins traffic most of the circulating cholesterol, a person can have seemingly healthy values, while disease progresses steadily. Type 2 diabetes has potential for changing lipoprotein ratios, favoring smaller molecules, thus promoting arterial plaques. That phenomenon explained why most people suffering from diabetes mellitus actually died of atherosclerotic complications.

Michael Brown and Joseph Goldstein, the 1985 Nobelists for Chemistry, introduced a new concept about cholesterol in cardiovascular disease - i.e. malady arose not from the molecule itself, or its lipoprotein configuration, but from genetic defects in the molecule's feedback control, specifically, genes encoding the low density lipoprotein receptor on cell membranes. They discovered that these receptors controlled whether or not cells synthesize cholesterol internally. Normally, cholesterol intake from food signals cells to reduce internal synthesis, but in extreme cases, where

\footnotetext{
${ }^{14}$ R. T. Ravenholt, "Tobaccosis," in Kenneth Kiple, ed., The Cambridge World History of Human Diseases (New York: Cambridge University Press, 1993) p. 182; Joel D. Howell, "Concepts of HeartRelated Diseases," in Kiple, ed., The Cambridge World History of Human Diseases, p. 94.
}

genetic mutations have greatly diminished those receptors on the cell surfaces, protein messages proceed unchecked and cause cells to increase their cholesterol production on the order of fivefold. Sufferers of this inherited "familial hypercholesterolemia" can have concentrations of 600 to 1000 $\mathrm{mg} / \mathrm{dl}$ and seldom survive childhood because of arterial clogs throughout their bodies. As much as describing the molecular biology of a disease, Brown and Goldstein defined how a cell membrane receptor normally functioned as a communicator over an internal pathway from one cellular organelle to another, regulating biosynthesis involving acetate (a simple two-carbon substrate) and at least thirty enzymes that work in coordination. As Brown and Goldstein surmised in their Nobel address: "Studies of this [LDL] receptor taught us about receptor-mediated endocytosis and the novel route by which receptors cycle in and out of cells. We have learned that receptors contain multiple functional domains that direct each step in this movement and that these domains are encoded on exons that can be shared among many proteins. We have learned that genetic defects in the receptor can cause cholesterol to accumulate in plasma, producing premature atherosclerosis." And, in these observations, they explained a complex phenomenon contributing to the principal cause of death among people in the developed world. ${ }^{15}$

Such findings about smoking and diet, flowing from the Framingham study but with supporting research, established "behavior" as a leading cause of coronary heart disease, but the methods, concepts and implications in time altered the understanding of many metabolic disorders. Before then, however, it was the decline of heart disease-related deaths that was so dramatic — down 20\% between 1968 and 1978. One risk factor study from Scotland found that treatment (medical) accounted for about $40 \%$ of the falling mortality, while prevention (public health) stood for $51 \%$. Confirmation of these figures came in from Australia and Finland. An American study, from the Centers for Disease Control and Prevention in 2007, concluded that from 1980 to 2000 age-adjusted

\footnotetext{
${ }^{15}$ Michael S. Brown and Joseph L. Goldstein, "A Receptor-Mediated Pathway for Cholesterol Homeostasis," Nobel lecture for Physiology or Medicine, 9 December 1985, online at http://nobelprize. org/medicine/laureates/1985.html; Guyton and Hall, Textbook of Medical Physiology, p. 874. Brown and Goldstein showed that the LDL-receptor is a glycoprotein of cell membranes made up of a chain of 839 amino acids (767 of them embedded in the membrane and 22 dangling into the cytoplasm). Defects in this molecule arise from the chain within the cell, having too few amino acids or ones in non-functioning configuration which disable the receptor from carrying LDLs into lysomes where the LDL and the cholesterol they carry are cleaved (separated). The LDL receptor then returns to the membrane surface to work again; the cholesterol goes into processes for membrane construction, vitamin D synthesis or hormone and bile acid synthesis.
} 
deaths from coronary heart disease fell from 542.9 to 266.8 deaths per 100,000 population among men, and from 263.3 to 134.4 per 100,000 women — with these declines about equally attributable to reductions in risk factors and evidencebased medical therapies. ${ }^{16}$

Similarly, stroke mortality in the US declined, from about 99 deaths/100,000 population in 1979 to 40/100,000 in 2007. This trend, however, began from the start of the $20^{\text {th }}$ century, though the decline accelerated to about five percent per year after 1975. Epidemiologists looked at many factors that could explain this - e.g. intensive glucose lowering, hyperlipidemia treatment, stroke systems of care, exercise and obesity, air pollution - and concluded that while several factors had a minimal or modest impact, the most significant influence came from reducing blood pressure, particularly systolic pressure. In 2007, stroke, which had been the second leading cause of premature death in 1950, fell to fourth, behind chronic lung disease (i.e. coronary heart disease, cancer, chronic lung disease, and stroke). ${ }^{17}$

Because the risk factors for cardiovascular disease correspond to cancer too, declining mortality figures for one track to the other, though in a slightly different time frame. Over the past 25 years, cancer mortality has fallen by $27 \%$. And new cancer diagnoses have declined recently by $2 \%$ a year. Some cancer types with the highest mortality have shown the greatest decline: lung deaths, 1990-2016, 48\%; breast, 1989-2016, 40\%; prostate, 1993-2016, 40\%, colorectal, 1990-2016, 53\%. And, again, causes for this decline were in behavior changes (largely smoking cessation) and medical attention (especially early detection). ${ }^{18}$

Knocking back these three great killers - heart disease, cancer and stroke - shared health acclaim of the $20^{\text {th }}$ century along with dramatic success against infectious diseases. But, into the $21^{\text {st }}$ century, troubling signs began to creep in, casting doubt on assumptions that rates of

\footnotetext{
${ }^{16}$ Jones and Greene, "The Decline and Rise of Coronary Heart Disease: Understanding Public Health Catastrophism," American Journal of Public Health, July 2013 (103: 7), pp. 1207-1218; Ford ES, Ajani UA, Croft JB, Critchley JA, Labarthe DR, Kottke TE, Giles WH, Capewell, "Explaining the decrease in U.S. deaths from coronary disease, 1980-2000," New England Journal of Medicine (2007 Jun 7, 356 (23): 2388-98, online: https://www.ncbi.nlm.nih.gov/ pubmed/17554120

${ }^{17}$ American Heart Association/American Stroke Association, "Factors Influencing the Decline of Stroke Mortality," Stroke, January 2014 (45:1): 315-353, online: https://www.ncbi.nlm.nih.gov/pmc/articles/ PMC5995123/

${ }^{18}$ Stacy Simon for the American Cancer Society, "Facts and Figures 2019: US Cancer Death Rate has Dropped 27\% in 25 Years," online: https://www.cancer.org/latest-news/facts-and-figures-2019.html
}

improving health and extending life expectancy would continue. Some wondered if these features had plateaued or even turned around.

Rising childhood obesity was particularly worrisome. A 2001 article in the Journal of the American Medical Association emphasized the connection between obesity and Type 2 diabetes as an "impending crisis" among children. Besides this disturbing link itself, a basic assumption that youth drove health until aging presented chronic diseases came into question. Another study in 2005 showed a $50 \%$ rise in obesity since 1960 , and concluded that, because of obesity, "the steady rise in life expectancy during the past two centuries may soon come to an end."19

And, that looks to be so. In 2015, 2016 and 2017, life expectancy in the US declined, not by a great amount, but sustained. Deaths among "Baby Boomers" (the 1946-1964 cohort) contributed to this, but 70,237 drug overdose fatalities and 47,000 suicides in 2017 fell heaviest on people between the ages of 24 and 44, when they should have been in prime health. Rural communities presented a worse picture than some urban ones. In Kentucky, eight counties had falling life expectancy, with Owsley County, in the eastern coalfield region, having the greatest decline - more than two years. The 2010 US Census reported that Owsley County had the second highest rate of children's poverty, and, by family income, Owsley was the poorest in the nation. As a state, Kentucky ranked sixth lowest, but Mississippi had the shortest life expectancy at 75 years - almost three years below the national average. WestVirginia stood only better than Mississippi, but the "Mountain State" ranked highest for obesity, hypertension, and diabetes, and among the highest for opioid abuse and suicide. ${ }^{20}$ In 2015, US Census officials started tabulating findings at the neighborhood level and one of the most troubling portrayals was the west end neighborhood of Huntington, WV. Over a decade, the city of Huntington, on the Ohio River in

\footnotetext{
${ }^{19}$ Jones and Greene, "Decline and Rise of Coronary Heart Disease," p. 1210; S. J. Olshansky, et al, "A Potential Decline in Life Expectancy in the United States in the $21^{\text {st }}$ Century, New England Journal of Medicine, 2005 Mar. 17, 352 (11): 1138-45, online at https://www. ncbi.nlm.nih.gov/pubmed/15784668

${ }^{20}$ Laura Joszt, "CDC Data: Life Expectancy Decreases as Deaths from Suicide, Drug Overdose Increase," Nov. 30, 2018, online: https://www.ajmc.com/focus-of-the-week/cdc-data-life-expectancy-decreases-as-deaths-from-suicide-drug-overdose-increase; Hristina Byrnes and Thomas C. Frolich, "Life Expectancy in the US: You're Most Likely to Live a Long Life in Hawaii and California," USA Today, Feb. 21, 2019, online: https://www.usatoday.com/story/ money/2019/02/21/average-life-expectancy-in-the-us-hawaiitop-state-for-a-long-life/39018551/; Mike Stobbe, "To Understand Life Expectancy Decline in the U.S., Start in West Virginia," Associated Press to the Denver Post, Dec. 18, 2018, online: https://www. apnews.com/f1915b8dafdb462986883142ed2ccac6
} 
the far south west of the state, had fought back against being described as the unhealthiest city in America. Obesity and diabetes rates improved, though hypertension and stroke incidences remained as serious problems. But then, opioid addiction advanced sharply, with adult deaths and children forced into foster care. West-end Huntington life expectancy at birth now is only 62 years, or about what it was for the nation when Franklin Roosevelt signed the Social Security Act in 1935. For comparison, life expectancy at birth in impoverished Haiti is 63.5 years. ${ }^{21}$

The concepts of life expectancy and healthy life expectancy have roots in the insurance industry, going back to the $19^{\text {th }}$ century. Sheppard Homans, working as an actuary for the Mutual Life Insurance Company of New York (MONY, the oldest continuous writer of life insurance in the US, founded in 1842), compiled the first life table, called the "American Experience Table," in 1868. This projected life expectance at any age before 65 , and found use in setting safe levels for issuing policies and for annuity reserves. With Social Security legislation (1935) and Medicare (1965), public insurance took health considerations into account, which prompted actuaries to consider health expectancy, not just years of life, into the economic equation. This, then, created a dual standard for population health assessment - life expectancy and healthy life expectancy. Hawaii has both the highest life expectancy at age 65 , an additional 21.3 years, but the healthy life expectancy is 16.2 years or $75.9 \%$ of their life length potential. Mississippians, at the other end of the scale, can expect to live 17.5 years after age 65 , but only 10.8 years of good health (61.5\%). Sixty-five year old Kentuckians and West Virginians can only expect about 17 and half years for life expectancy, and 11 years more for healthy life. Internationally, Americans might be surprised that China has overtaken the United States for health life expectancy. China ranks $37^{\text {th }}$ in the world; the US came in at $40^{\text {th }} .22$

Current levels of life expectancy and healthy life expectancy cannot be projected into the future, for the better or worse. But it is possible to imagine how people could live longer by delaying aging and suppressing adult disabilities and diseases. First though there's the matter of a person's chronological age and biological age. Birthday candles are a

\footnotetext{
${ }^{21}$ Stobbe, ibid; life expectancy in Haiti, https://borgenproject.org/ top-10-facts-about-life-expectancy-in-haiti/

${ }^{22}$ CDC Morbidity and Mortality Weekly Report, July 19, 2013/62 (28): 561-566, "State-Specific Healthy Life Expectancy at Age 65 Years — United States, 2007-2009," online: https://www.cdc. gov/mmwr/preview/mmwrhtml/mm6228a1.htm; Tom Miles, "China Overtakes U.S. for Healthy Lifespan: WHO Data," Reuters, May 30, 2018, online: https://www.reuters.com/article/us-health-lifespan/ china-overtakes-u-s-for-healthy-lifespan-who-data-idUSKCN1IV15L
}

measure of chronological age and that amount is finite. Biological age has not been defined because there are too many variables, based on the fact that tissues in the body lose vitality at different rates. Perhaps machine learning and artificial intelligence will make a timeline of biological aging possible in the future, but for now it's largely about appearances. Some people look younger than their chronological age; some look older because of their biological age. It's also so that aging and disease involve different processes, though, as one authority observed, "aging is what sets the morbidity process in action." Simply, aging, while normal in itself, exposes tissues to the abnormal states of disease because DNA, RNA and proteins accumulate alterations from their environment. Both accelerated aging and delayed aging can occur, independent of chronological aging. ${ }^{23}$

The US Social Security Administration and research demographers have made projections (i.e. informed guesses) about life expectancy and health expectancy by the turn of the $22^{\text {nd }}$ century. Government statisticians suppose life expectancy will increase by one year per decade; academic sources double that projection; so, by either count, US average life expectancy will not reach 100 years by 2100 , though Social Security projects 87 years (up from 78 years in 2010), and the academics push that number at 96 years. Still, average life expectancy of either 87 or 96 years means a much larger number of centenarians will survive. Health-adjusted life expectancy, however, subtracts about six and a half years from average life expectancy at age 60 . The question then becomes how can health-adjusted life expectancy be extended by compressing biological aging while also avoiding disease and injury? The answer involves people becoming participants in their own and the society's health, scientific breakthroughs, economic support for health advancement, and political leadership for population health. ${ }^{24}$

Even before the Framingham Heart Study documented "risk factors" for disease, a Public Health Service physician, Halbert L. Dunn, M.D., gave a series of lectures in Arlington, VA that became his widely read book High Level Wellness, published in 1961. Dunn quoted the World Health Organization's definition of health in 1948: "Health is a state of complete

\footnotetext{
${ }^{23}$ Katz S, Branch LG, Branson MH, Papsidero JA, Beck JC, Greer DS, "Active Life Expectancy," New England Journal of Medicine 1983 Nov 17: 309 (20): 1218-1224, online abstract: https://www.ncbi. nIm.nih.gov/pubmed/6633571; Eileen M. Crimmins, "Lifespan and Healthspan: Past, Present and Future," Gerontologist 2015, Dec. 15, 55 (6): 901-911, online https://academic.oup.com/gerontologist/ article/55/6/901/2605490; Leonard Hayflick, How and Why We Age (New York: Ballantine Books, 1994, pp. 12-13, 44-48.

24 "Understanding Healthy Life Expectancy," online: https:// www.verywellhealth.com/understanding-healthy-life-expectancy-2223919
} 
physical, mental and social well-being and not merely the absence of disease or infirmity." And, he wondered why healthcare workers commonly forgot health's three-dimensions. "High level wellness," he defined as "an integrated method of functioning which is oriented toward maximizing the potential of which the individual is capable. It requires that the individual maintain a continuum of balance and purposeful direction within the environment where he is functioning." It made little difference to physicians who understood diseases in the context of academic definitions, or to the general public who supposed the conquest of disease mattered most, that wellness argued for prevention more than treatment. In those mindsets, wellness was a brew of alternative medicine theories and practices that didn't measure up to conventional thinking. ${ }^{25}$

Wars have long affected health and medical thinking, but the Vietnam War had a distinctive influence - questioning authority. Antiwar protestors challenged political, social and economic norms that World War II had created. The civil rights and women's rights movements pushed the questioning further. And the healthcare professions could not avoid criticism for being narrowly focused on diseases that required increasingly expensive treatments, as well as for racism and sexism in medical school enrollments, minorities being excluded from clinical trials, and women leaders in policy-making roles. One personality in particular connects the Vietnam War with a broader interpretation of health and medicine: Tom Harkin. During the war he served as a Navy pilot in Japan with occasional missions to Vietnam; then, just as the war ended in 1975, he won election from lowa to the US House of Representatives, and later became a US Senator and chair of the Senate Committee on Health, Education, Labor and Pensions. In 1991, he promoted the National Institutes of Health to open the Office of Alternative Medicine, which eventually became the National Center for Complementary and Integrative Medicine (1998). This bureau encountered much criticism for its scientific weakness and alleged quackery, but over time it gave credence to mindbody medicine, mental healing, dietary supplements, and other regimes - which were elements of Dunn's "high level wellness." When Congress increased the Center's budget from $\$ 20 \mathrm{~m}$ to $\$ 50 \mathrm{~m}$ without dissent in 1999 , wellness had won a foothold in healthcare along with other alternatives: genomics and gene therapy, predictive informatics, novel medical devices and surgical robots, telemedicine and wearable sensors. ${ }^{26}$

\footnotetext{
${ }^{25}$ Christian Nordquist, "Health: What does good health really mean?," Medical News Today, 31 July 2017, online: https://www.medicalnewstoday.com/articles/150999.php; Halbert L. Dunn, M.D., Ph.D., High Level Wellness (Arlington, VA: R. W. Beatty, Ltd, 1961), pp. 4-5.

${ }^{26}$ Jane Norman, "The Chance of a Lifetime Arrives for Tom Harkin," September 14, 2009, online: https://www.commonwealthfund.org/
}

What all this comes to is this: it may be possible to extend average life expectance slowly over several decades, and average healthy life expectancy to a greater level in a shorter time. In 2007 at the MedicalAutomation.com conference in Lansdowne, VA, Dr. Brad Perkins - then chief strategy and innovation officer at the Centers for Disease Control and Prevention - listed the factors and their weight for preventing premature death: behavior, $40 \%$; genetics, $30^{\text {th }}$; social factors, $15 \%$; access to healthcare, $10 \%$ and environmental hazards, $5 \%$. This roughly tracks the Framingham and related epidemiological studies. ${ }^{27}$ Each of these objectives holds multiple tactics for health improvement.

\section{Behavior}

Framingham's "risk factor" analysis still rings true: smoking cessation, weight loss and exercise, lowering blood pressure, cholesterol and blood sugar levels remain the foundation for personal and societal health culture. But each factor actually involves complex biological processes. For example, the benefit of weight loss is widely known, if not as widely practiced, though the molecular effect of "calorie restriction" on longevity is now becoming clearer. Eating less, particularly less of the amino acid methionine, decreased the activity of a protein named "mTOR." In younger people, more mTOR activity is desirable because it regulates cell growth, proliferation and other essential processes, but from about age 60, mTOR's positive contribution reverses as it becomes implicated in the altered proteins of aging, cancer, diabetes and Alzheimer's disease. mTOR actually exists as a protein complex, and pharmaceutical researchers have been long in search of a druggable target that separates mTOR's beneficial and harmful effects. If and when this happens, health and longevity may have somewhat more time to spend together. Meanwhile, though, a modest eating habit, learned in childhood, is a behavior favoring longer, healthier life. ${ }^{28}$

A salt-restricted diet and regular, undisturbed sleep are two other behaviors that are generally understood as

publications/newsletter-article/chance-lifetime-arrives-tom-harkin; "The Politics of Alternative Medicine," Science 265 (30 September 1994): 2000, online: https://science.sciencemag.org/ content/265/5181/2000

${ }^{27}$ Brad Perkins, MedicalAutomation.org conference, October 29, 2007.

${ }^{28}$ Ed Young, "The two faces of rapamycin — why a life-extending drug also increases risk of diabetes," Discovery Magazine, March 30, 2012; online: http://blogs.discovermagazine.com/notrocketscience/2012/03/30/the-two-faces-of-rapamycin-why-a-life-extending-drug-also-increases-risk-of-diabetes/; James A. Timmons, et al, "Longevity-related molecular pathways are subject to midlife 'switch' in humans," Aging Cell, 6 June 2019, online: https://onlinelibrary.wiley.com/doi/10.1111/acel.12970 
beneficial, without understanding their complexity. Controversy over dietary salt raising blood pressure has gone back and forth since the late $19^{\text {th }}$ century, which one source called "the salt wars." It started with several European scientists trying to explain kidney swelling found in cases of Bright's disease. Retaining water in the vascular system seemed to explain this observation, and salt figured as a cause. The solution was a salt restricted diet. Many variations on this theme followed, with perhaps most notably Walter Kempner, MD at Duke University promoting "the Rice Diet." Kempner was a German Jewish immigrant who fled with his mother and brother the rise of German nationalism. He came to Duke in 1934 with a fine pedigree. Both of his parents had worked under the renowned German pathologist Robert Koch, and they had studied the effect of salt in food spoilage. When he started treating patients who presented "malignant hypertension" (i.e. blood pressure above 180/120), Kempner had only one possible therapy, changes in diet. The Rice Diet consisted of rice and fruit, amounting to about 2,000 calories a day. And, it was famously low in salt. Adherents lost weight; so critics claimed salt restriction was only incidental to lower blood pressure from less body mass. But of 192 patients in Kempner's original cohort, only 25 died — from what had been considered a uniformly fatal disorder. His success drew Hollywood celebrities and during his tenure at Duke, Kempner treated over 18,000 patients, and after his death in 1997, The Rice Diet Program, as a private business, continued until $2013 .{ }^{29}$

New antihypertensive drugs during the 1970s diverted attention away from dietary solutions like Kempner's Rice Diet, but several clinical trials showed that drugs and salt restriction had synergistic benefit. Some public health authorities made blanket recommendations to reduce dietary salt. In 2012, the World Health Organization urged all its member countries to advocate lowering salt consumption (less than $5 \mathrm{~g}$ daily for adults) and released this statement: "These recommendations apply to all individuals, with or without high blood pressure (including pregnant and lactating women), except individuals with illnesses or those taking drug therapy that may lead to low sodium levels or acute build-up of body water, or require physician-supervised diets (e.g. patients with heart failure and those with type 1 diabetes). In these subpopulations, there may be a particular relationship between

\footnotetext{
${ }^{29}$ James J. DiNicotantonio and James H. O'Keefe, "The History of the Salt Wars," The American Journal of Medicine, 2017; 130: 1011-1014 and online, https://www.amjmed.com/article/S00029343(17)30508-9/pdf; Philip Klemmer, Clarence E. Grim, and Frederich C. Luft, "Who and What Drove Walter Kempner? The Rice Diet Revisited," Hypertension, 2014; 64: 684-688 and online, https://www. ahajournals.org/doi/pdf/10.1161/HYPERTENSIONAHA.114.03946; Associated Press, September 13, 2013, "Rice Diet center shuts its doors after 70 years," online, https://www.nydailynews.com/lifestyle/health/rice-diet-center-closes-70-years-article-1.1451274.
}

sodium intake and the health outcomes sought." This exception recognized that dietary salt has a spectrum of reactions: in normotensive people, normotensives with salt sensitivity, hypertensives without salt sensitivity, hypertensives with salt sensitivity, and "salt wasters" (who need added salt to remain healthy - even to remain alive). Researchers are now attempting to create an inexpensive and accurate diagnostic for salt sensitivity based on urine markers that will sort out those who are in most danger of dying from heart attack, stroke or kidney failure - which may be more than two-thirds of a billion people worldwide. ${ }^{30}$

Oddly enough, sleep monitoring may have surrogate markers for hypertension and salt sensitive hypertension. Sleep happens in a five stage cycle. Two periods of "nonREM" sleep (REM refers to deep sleep when rapid eye movement happens) occur before and after REM. During deep sleep, blood pressure rises, but then falls during non-REM. A failure to make that dip indicates possible (or probable) damage to capillaries in the brain, eye, heart, and kidney. And, it is during non-REM sleep when the body repairs or replaces its tissues, including immune system cells. Recording both blood pressure and sleep quality, passively, overnight would provide baseline data when the wearer has the least physical and emotional activity. Several engineering companies are now developing wearable devices that measure blood pressure passively. One company, Sensogram Technologies (Plano, TX) makes a ring that measures blood pressure, heart rate, oxygen saturation, respiration, and ECG, with future objectives of tracking stroke volume, sleep quality, cardiac output and atrial fibrillation. Results feed to a smartphone app. Devices such as this are only as useful as the patient's adherence, much like a glucometer, but they do give users health information that has never been this accessible before to change everyday behaviors. While wearables are aimed at the consumer

\footnotetext{
${ }^{30}$ Vecichi Batuman, "Salt and Hypertension: Why is there still a debate?," Kidney International Supplements, 2013 Dec; 3 (4): 316-320, and online, https://www.ncbi.nlm.nih.gov/pmc/articles/PMC4089608/; Theodore A. Kotchen, "Historical Trends and Milestones in Hypertension Research: A Model of the Process of Translational Research," Hypertension 2011, 58: 522-538, and online, https://www.ahajournals.org/doi/10.1161/HYPERTENSIONAHA.111.177766; "Salt Reduction," World Health Organization, 30 June 2016, and online, https://www.who.int/news-room/factsheets/detail/salt-reduction; Michael H. Alderman, "Salt Sensitivity: state of science," Hypertension 2017, 35 (11): 2175, online, https:// journals.Iww.com/jhypertension/Fulltext/2017/11000/Salt_sensitivity_state_of_the_science.9.aspx Robin Felder, Marquitta J. White, Scott M. Williams, and Pedro A. Jose, "Diagnostic Tools for Hypertension and Salt Sensitivity Testing," Current Opinions in Nephrology and Hypertension, 2012, online: https://www.ncbi.nlm. nih.gov/pmc/articles/PMC3724405/ .
} 
market, wider use would generate enormous amounts of data that actually could redefine what it means to be "healthy." 31

\section{Genetics}

After behavioral factors aimed at preventing premature death, genetics, or more broadly, molecular medicine, has the second greatest potential influence. Since the Human Genome Project completed its "first draft," "omics" of several kinds epigenomics, proteomics, lipidomics, glycomics, transcriptomics, toponomics, microbiomics - have energized an approach to health that systems biologist Leroy Hood calls "the 4 P's": predictive, preventative, personalized and participatory. Critics say this is mostly "promisory science," but criticism is part of the doubt that makes science work (Fig. 2). ${ }^{32}$

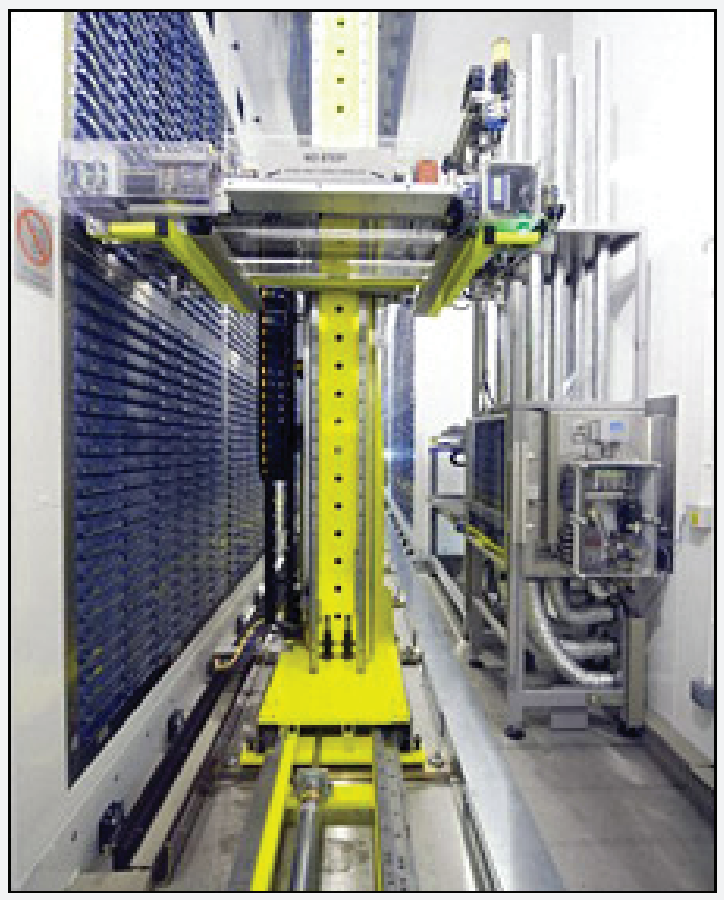

Figure 2. At a British biorepository a robot retries and returns many thousands of tissue samples from a freezer for "omics" testing. Source: The Automation Partnership.

\footnotetext{
${ }^{31}$ Berteotti C; Franzini C; Lenzi P; Zoccoli G; Silvani A. Surges of arterial pressure during REM sleep in spontaneously hypertensive rats. SLEEP 2008; 31(1): 111-117; "SensoRing" and "SensoScan" are products from Sensogram Technologies, online, https://www. sensogram.com/; Hanae Armitage, "Study Shows How Big Data Can be Used for Personal Health," Stanford University News Center, May 2019, online, https://med.stanford.edu/news/all-news/2019/05/ study-shows-how-big-data-can-be-used-for-personal-health.html

32 "Promissory science," Jones and Greene, "Decline and Rise of Coronary Heart Disease," p. 1216.
}

In their book, Living to 100, physician Thomas Perls and neuropsychologist Margery Silver reported their findings from "The New England Centenarian Study." This was the first North American study of the world's oldest people. Their first observation was that "the key to preserving health and vitality, it appears, lies not in learning how people stay young, but in understanding how well they age." And, they concluded that Centenarians are far more likely to have a near lifetime of excellent health, followed by a quick decline before death." What, then, are the genetics of healthy aging ${ }^{33}$

Several US and international research groups began to look into population genetics to find sequences for both healthy and disease states. deCODE Genetics began in 1996 and eventually carried out DNA sequencing on about half of Iceland's people. A few years later, Lynx Therapeutics introduced the first "next generation sequencer" which allowed enormously faster processing at a lower cost. Other machines and projects followed. In 2007, the Scripps Translational Science Institute (La Jolla, CA) launched its "Wellderly" study, and five years later China began its Population Genomics and Genetics Project, the UK founded its " 100,000 Genomes Project," and two Australian universities set out to do whole genome sequencing of 4,000 individuals (aged 70 or above, with no reported cardiovascular disease, cancer or dementia) for a "Medical Genome Reference Book." Supporting the enormous data load that comes from nucleic acid sequencing, artificial intelligence can now interrogate those sequences for health insights that have never been possible before (Fig. 3). ${ }^{34}$

${ }^{33}$ Thomas T. Perls and Margery Hutter Silver, Living to 100: Lessons in Living to Your Maximum Potential at Any Age (New York: Basic Books, 1999), p. xiii and p. 18.

${ }^{34}$ Jerzy K. Kulski, "Next-Generation Sequencing - An Overview of the History, Tools, and "Omic" Applications," January 14, 2016, published online: https://www.intechopen.com/books/nextgeneration-sequencing-advances-applications-and-challenges/ next-generation-sequencing-an-overview-of-the-history-toolsand-omic-applications; Marina Barba, Henryk Czosnek and Ahmed Halid, "Historical Perspective, Development and Applications of Next Generation Sequencing in Plant Virology," Viruses, 2014 Jan 6 (1): 106-136 and online, https://www.ncbi.nlm.nih.gov/pmc/articles/PMC3917434/ deCODE Genetics, https://www.decode.com/ research/; Zhang, C, et al, "PGG.Population: a database for understanding the genomic diversity and genetic ancestry of human populations," Nucleic Acids Research, 2018 Jan 446 (D1): D984-D993 and online, https://www.ncbi.nlm.nih.gov/pubmed/29112749; "The 100,000 Genomes Project," mainly aimed at discovering the genetics of rare diseases, but it includes non-affected family members, https://www.genomicsengland.co.uk/about-genomics-england/the100000-genomes-project/; "MGRB Adds 4,000 Healthy Elderly to Database," Dark Daily, May 24, 2019, online, https://www.darkdaily. 


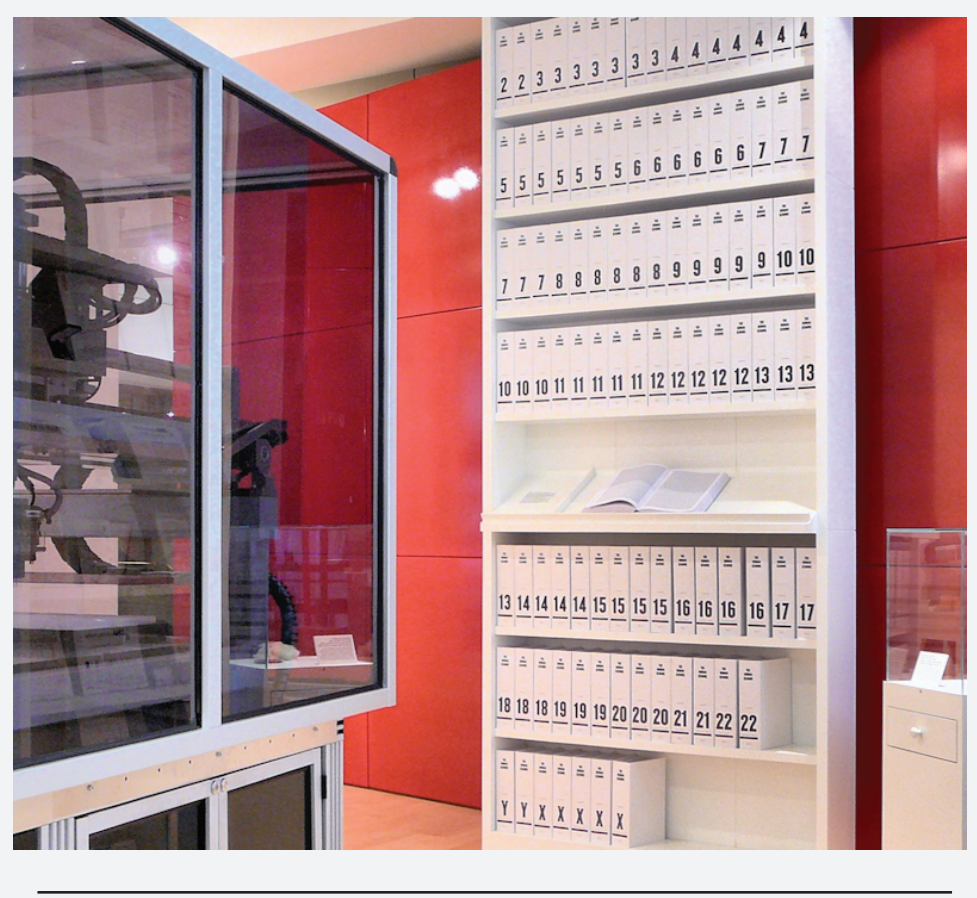

Figure 3. The Human Genome Catalog, Cambridge University. Source: the Sanger Center. health is the best strategy against disease and disability (Fig. 4). ${ }^{35}$

Between the bookends of infancy and old age, new diagnostic technologies, other than sequencing, may be able to "catch" health-threatening conditions before they become full blown diseases. Mass spectroscopy will remain the workhorse of proteomics in core laboratories, but from biomarker discovery to microfluidics devices that can capture circulating tumor cells, and biosensors which measure purines from brain cells that are deprived of oxygen (indicating a stroke), molecular diagnostics are moving from traditional testing venues, to doctor's offices, drug stores, patient homes and smartphones. A recent report from Australian scientists found a distinct pattern of DNA methylation in breast cancer, which then presented in other cancers - suggesting a possible "universal cancer biomarker." And, this may also be a marker for faster aging. Timing, of

Figuring out the "omics" of healthy elders should suggest new molecular targets for the major diseases of adults, but a similar opportunity exists on the other end of the age spectrum. Since 1970, nearly every baby born in the United States has been screened using a method Dr. Robert Guthrie developed in 1958. The procedure relies on drawing a few drops of blood from the baby's heel onto a filter paper. Every state requires this newborn screening, but states differ slightly on the number of disorders being tested; most require 34, including ones for phenylketonuria, cystic fibrosis, sickle cell anemia, Maple Syrup Urine Disease, glactosemia, and homocystinuria. No DNA sequencing is done, but the test papers are kept in archives of the state health agencies. Some states do this testing for free; others charge between $\$ 15$ and $\$ 150$. With advances in sequencers and artificial intelligence data analysis, it is easily conceivable that newborn tests will include whole genome or whole exome sequencing, at a cost that will make it as commonplace as the Guthrie test. The usefulness of this is that a baby has a baseline measure of its genetic health which can be reexamined to compare with subsequent sequencing over a lifetime. If half of American babies born since 2000 actually live to age 100 as predicted, tracking and maintaining their long term

com/medical-genome-reference-bank-uses-whole-genome-sequencing-to-add-4000-healthy-older-adults-to-its-huge-database/ course, will tell how quickly molecular biology becomes molecular medicine. It now takes on average seventeen years for a worthwhile discovery or innovation to make its way into

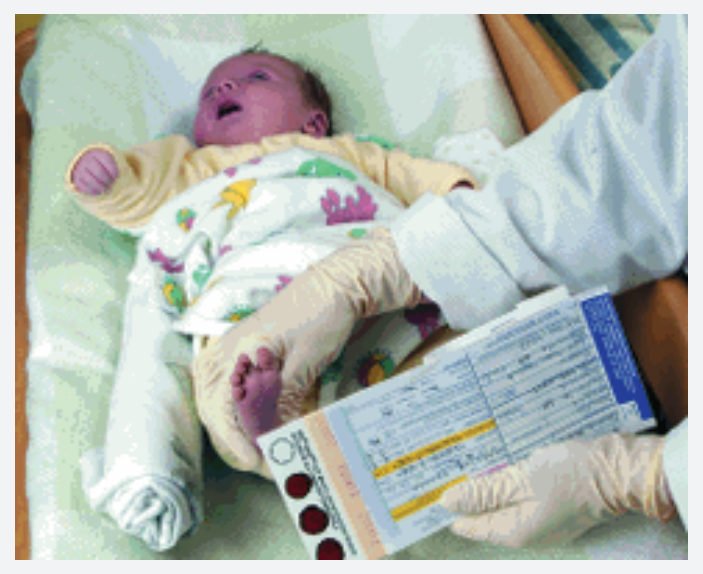

Figure 4. The Guthrie neonatal screening test has been applied to almost every birth in the United States since 1970.

\footnotetext{
${ }^{35}$ Kaare Christensen, Gabriele Doblhammer, Roland Paul and James Vaupel, "Ageing populations: The challenges ahead," Lancet, 2009 Oct. 3: 374 (9696): 1196-1208, p. 1198, online, https://www.ncbi. nlm.nih.gov/pmc/articles/PMC2810516/
} 


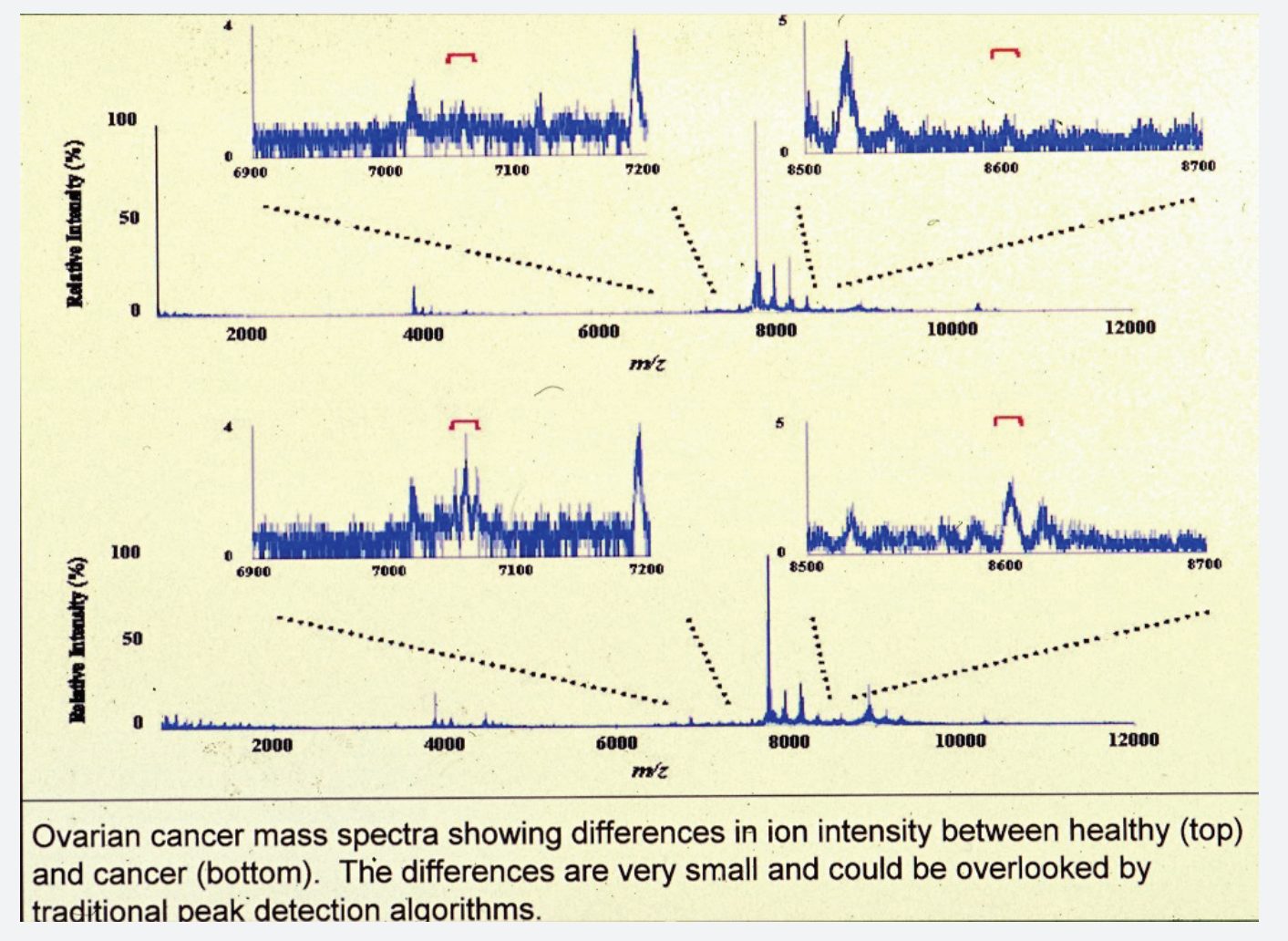

Figure 5. Mass spectrometer analysis of normal ovarian and ovarian cancer tissue. Source: Dr. Lance Liotta, George Mason University.

clinical practice, but medical research is a global enterprise, and many countries, working on the same problem of healthy aging, should accelerate choice-making in peoples' lives (Fig. 5). ${ }^{36}$

\section{Social factors}

Health epidemiologists wrestle with measuring the "social determinants of health," but the simple truth is that American society doesn't really believe that health precedes and influences all other goals and accomplishments. Instead, it accepts health disparities as "normal," usually prefers decentralized solutions to national problems (i.e. states' rights), and embraces an "it's the economy, stupid!" priority over all

\footnotetext{
${ }^{36}$ Jason E. McDermott, et al (Pacific Northwest National Laboratory, Richland, WA), "Challenges in Biomarker Discovery: Combining Expert Insight with Statistical Analysis of Complex Omics Data," Expert Opinion in Medical Diagnostics, 2013 Jan: 7 (1): 37-51, online https://www.ncbi.nlm.nih.gov/pmc/articles/PMC3548234/; Cory Nealon, University of Buffalo news, "Portable Cancer Test Uses Smartphone, New Gold Biosensor," Oct 3, 2018, online, https://www. aau.edu/research-scholarship/featured-research-topics/portablecancer-test-uses-smartphone-new-gold
}

except security threats from abroad. It has not always been this way.

Poverty drives poor health, and this is more complicated than just low income levels. What emerges is a culture of despair - the opposite of a culture of health. Income is a measurement to set thresholds for government programs eligibility, based on yearly Census Bureau sampling and the Consumer Price Index. The current poverty threshold (2017 figures) for a single person under age 65 is $\$ 12,793$, rising to $\$ 25,707$ for a family of four, with two children (about $\$ 6,400$ per person a year). By that measure, 39.7 million Americans are impoverished, i.e. 1 in 8 or $12.3 \%$. Other estimates place the poverty level as high as $17 \% .{ }^{37}$

\footnotetext{
${ }^{37}$ Steven Pressman, "The Range of Poverty in America," US News \& World Report, Sept. 12, 2018, online, https://www.usnews.com/ news/healthiest-communities/articles/2018-09-12/poverty-inamerica-new-census-data-paint-an-unpleasant-picture is there a biological characteristic for poverty? A study of young adults in the Philipinnes assayed DNA methylation in leukocytes from 489 participants with a mean age of 20.9 years found that a pattern methylation at sites where a guanine nucleotide followed cysteine. The methylation changed gene expression levels in individuals identifies
} 
The roots of American poverty are deep, going back to the eras of slavery, the Indian wars, and industrial exploitation of women, children and immigrants. Arguments against current federal health improvement programs resonate with historical reasons that underlay every kind of discrimination. Both Presidents Roosevelt sought to improve health security: Theodore, when he supported the first national health insurance plan during his 1912 Progressive Party campaign, and Franklin with his signing the 1935 Social Security Act. The original Social Security bill included a provision to "study" national health insurance, which the American Medical Association opposed unless the program was voluntary and under control of county-level medical organizations. Social Security became law, but without including national health insurance. $^{38}$

President Truman picked up the cause of national health insurance, but conservatives blocked that passage, and instead substituted the "Hill-Burton" Hospital and Construction Act of 1946, which gave federal grants for localities building private tax-exempt "community hospitals." The tax exemption supposedly supported "charity care," but without insurance contracts to control hospital prices, "costs" for uninsured care provided a cover for exaggerated tax relief. Hill-Burton also had a "separate but equal" clause that permitted racial segregation in southern hospitals, which also extended to blood donations. With a rising economy under President Kennedy, he ordered his staff to design a health initiative aimed to help the poor, but he died before that could materialize. Then, in his State of the Union address on January 8, 1964, President Johnson proposed an "unconditional war on poverty." (Almost everything he said bears repeating today: https://millercenter.org/the-presidency/presidentialspeeches/january-8-1964-state-union). Four months later, he spoke the term that characterized his efforts, "The Great Society." And on the strength of his landslide victory in the 1964 Presidential campaign, President Johnson signed the Voting Rights Act, the Elementary and Secondary Education Act, and the amendment to the 1935 Social Security Act which created Medicare and Medicaid. The American Medical Association opposed Medicare and backed an alternative and voluntary "Eldercare" of private insurance, but the final law made Medicare Part A compulsory under Social Security for hospitalization: Part B added subsidies for private insurance

as having low socioeconomic status (i.e. they were poor). Not all C-G sites were over expressed though most were and that related to immune function, skeletal development and nervous system development. Reported in the American Journal of Physical Anthropology, 16 February 2019, online, https: //doi.org/10.1002/ajpa.23800

${ }^{38}$ Paul Starr, The Social Transformation of American Medicine: The Rise of a Sovereign Profession and the Making of a Vast Industry (New York: Basic Books, 1982), p. 243, 266-269. to cover doctors' bills; Medicaid provided assistance to the states to cover expenses for the uninsured and poor. As sociologist Paul Starr pointed out, the two tracts carried different connotations. Medicare had the same status as Social Security, though critics railed against both as "socialism." But Medicaid carried the additional "stigma of public assistance." Johnson believed reducing poverty was possible and that would create "a greater sense of Union." Instead, race riots, antiwar protests, and "drop out" culture tore the Great Society to shreds. ${ }^{39}$

Coming to the present, the nation's health profile shows improvement over its state in the 1960 s, but it ranks $43^{\text {rd }}$ for life expectance among 224 nations in the CIA's World Factbook. South Korea and Greece stand higher than the US, with the three Axis countries of World War II all rating higher. The United States only holds a first in the cost of its healthcare. It's at least interesting to speculate what health in America would be like in terms of its social determinants at Japan's level-highest for a major nation. How would the availability of resources to meet daily needs (education, employment, food), social norms that diminish discrimination, less exposure to crime, greater social support, diminished poverty, quality schools, more transportation options, enhanced public safety change Americans' potential for its health standing in the world? Even short of being first, controlling obesity among children, addiction among young adults, and preventing suicides among mature adults would go a long way toward a healthier nation. That is possible, because it happened before. $^{40}$

\section{Healthcare}

The Center for Disease Control and Prevention's estimated that healthcare only contributes about $10 \%$ to preventing premature death, when Dr. Brad Perkins listed the five major factors a dozen years ago (in 2007). But that may need revising because of an avalanche of technology developments since then. New tools open new possibilities. Among many are telemedicine, regenerative medicine, and medical uses of artificial intelligence.

Telemedicine arose to overcome problems of distance between patients and providers. One of the early programs was the 1974 "Space Technology Applied to Rural Papago Advanced Health Care" (STARPAHC) linking the interests of the

\footnotetext{
${ }^{39}$ Rosemary A. Stevens, Charles E. Rosenbeg, and Lawton R. Burns, eds., History of Health Policy in the United States (New Brunswick, NJ: Rutgers University Press, 2006), p. 263; Starr, Social Transformation of American Medicine, pp. 369-370.

${ }^{40}$ Healthy People.gov, "Determinants of Health," online https:// www.healthypeople.gov/2020/about/foundation-health-measures/ Determinants-of-Health
} 
Indian Health Service and NASA. In order to draw funding from a domestic program, NASA built a microwave communications system that transmitted X-ray images, ECGs, and other data over a 134 miles between the Tohono 0'odham tribal seat at Sells, AZ and the IHS hospital in Phoenix. This became the starting point for the University of Arizona in Tucson (61 miles from Sells) to create an Arizona telemedicine program that reached Indian reservations, prisons and rural communities. Then, telemedicine took its own "giant leap for mankind" on September 7, 2001, when a French surgical team in New York city performed a cholecystectomy on a 68 year old woman in Strabourg, France, using a "ZEUS" surgical robot operating over fiber optic cable between the two sites - more than 3,800 miles apart. $^{41}$

The limiting issue for telemedicine has been insurance reimbursement. Several projects demonstrated effectiveness, but insurers held back payments until Medicare began covering telemedicine services in 2001, with certain restrictions. Medicaid did not consider telemedicine services as being different from office visits, and so offered coverage, but primarily for people living in rural areas. In 2019, Medicare is finalizing its telemedicine coverage under the "Medicare Advantage" program, which involves "Health Maintenance Organizations" and "Preferred Provider Organizations" providers. ${ }^{42}$

Telemedicine is a "disruptive innovation," to use Harvard professor Clayton Christensen's term, but Apple's introduction of the "iPhone" in 2007 disrupted telemedicine. The iPhone was not the first smartphone - i.e. a combined phone and computer with onscreen applications - but it holds half of the global market for these devices and app developers have created thousands of uses, with hundreds for healthcare. Telemedicine now extends to teleopthalmology, telepsychiatry, telehealth care coordination, clinical gait analysis and telerehabilitation, asthma in-home monitoring, rural consultations, prison health services, child abuse reporting, and auditory screening among others which have existed for a few years. ${ }^{43}$

\footnotetext{
${ }^{41}$ NASA, "A Brief History of NASA's Contribution to Telemedicine, NASA News, August 13, 2013, online, https://www.nasa.gov/ content/a-brief-history-of-nasa-s-contributions-to-telemedicine, "Operation Lindbergh," online, https://www.revolvy.com/page/Lindbergh-operation

${ }^{42}$ Centers for Medicare and Medicaid Services, "CMS finalizes policies to bring innovative telehealth benefits to Medicare Advantage," CMS Press Release, April 5, 2019, online: https://www.cms.gov/ newsroom/press-releases/cms-finalizes-policies-bring-innovativetelehealth-benefit-medicare-advantage Telemedicine is one way "Medicare for All" could be implemented, as a start.

${ }^{43}$ Examples of smartphone in health care: Sweat analysis, https:// www.sciencedaily.com/releases/2019/04/190417102737. htm; controlling neuromodulator for migraines, https://www. mddionline.com/smartphone-controlled-wearable-migraine-
}

While these medical applications for smartphones are each innovative in their own way, a greater transformation emerges from their kind. Smartphones handle data in digital formats, and each data bit is a piece of digital measurement. By aggregating the digital measurements from such things as single nucleotide polymorphisms, to gene expression patterns, to hundreds of test results (Acoustic Reflex Test to the Xylose Tolerance Test), medical images, electronic medical records, compliance and adherence information, and even "DLO" (daily life observations - all adding up to a new concept in healthcare, the digital patient. Health may never come down to being a computation problem, but if it moves in that direction "digital doctors" will be needed, and to that end the Digital Medicine Society formed in 2019. ${ }^{44}$

"Regenerative medicine" has some surprising roots, including a collaboration between two famous Nazi accommadationists, the French surgeon and Nobel laureate at the Rockefeller Institute for Medical Research Dr. Alexis Carrell, and the more famous transatlantic aviator, Charles Lindbergh. Lindbergh went to Carrell seeking help for his sister-in-law who was suffering from a failing heart. Carrell was a proponent that cells lived as long as they had a nutrient and oxygen supply, and Lindbergh engineered a heart pump that supposedly kept a heart alive outside the body. This resulted in their 1939 book titled The Culture of New Organs. As it turned out, though, heart cells, like other somatic cells of the body, have a limited number of doublings before they die — on average, about 50 doublings over a lifetime, known as "the Hayflick limit" (for cell anatomist Leonard Hayflick who discovered this at the Wistar Institute in Philadelphia during the 1960s).

device-wins-us-market-authorization?ADTRK=InformaMarkets\& elq_mid=8861\&elq_cid=46530; ultrasound transducer plugs into a smart phone, https://www.medgadget.com/2019/04/butterfly-iqmulti-purpose-pocket-sized-ultrasound-now-available-in-europe. $\mathrm{html}$; for listening to heart murmurs, https://www.fiercebiotech. com/medtech/fda-clears-first-ai-powered-mobile-app-to-catchheart-murmurs?mkt_tok=eyJpljoiWmpSak5tVTV0akkyTmp0aylsınQiOiJmNFIKdWYrTkRGNWRiajdraHB6am5wd2pNbWRpc1E4b0dFTkdkd2xidVF1U2pYWXAxNk10R25IdFIYRktcL2pGNmNYYWhVTzFZaHRoZmZqT1RWaTBmQ1wvVFIKeGk1cng4MIRQMnF3Y21DMm5ITTBtZ2UzQWVD0StaekNUdGJOV1ZcLyJ9\&mrkid=983495; for home urinalysis, https://www.darkdaily.com/fda-approves-smartphonebased-urinalysis-test-kit-for-at-home-use-that-matches-quality-ofclinical-laboratory-tests/, also see: https://www.aconlabs.com/us/ urinalysis/mission/urine-reagent-strips/; ovulation testing, http:// www.ehealthnews.eu/index.php?option=com_content\&view=articl e\&id=5706:brigham-researchers-develop-smartphone-based-ovulation-test\&catid=164:research; and BRCA1 assessment for breast cancer, https://www.medgadget.com/2018/11/point-of-care-brca1mutation-testing-in-20-minutes.html

${ }^{44}$ The Digital Medicine Society, see: https://www.dimesociety.org/ 
Two Canadian cancer researchers, James Till and Ernset McCulloch, reported the regenerative capability of hematopoietic tissue in bone marrow in 1963, and while they didn't coin the term "stem cell," they usually receive credit for giving birth to that concept. Advancing that technology came from two independent research groups - one led by Shinya Yamanaka at the University of Kyoto in 2006 for the "induction of pluripotent stem cells" from embryonic (mouse) tissue to skin cells, and the other from James Thomson's lab at the University of Wisconsin at Madison the following year with human embryonic stem cells. Yamanaka showed that induced pluripotency depended on altering just four genes, and with that, stem cells became a compelling strategy for regrowing tissues that time, injury or disease had worn away. ${ }^{45}$

Several university researchers showed remarkable success with tissue engineering. Anthony Atala, at the Wake Forest Institute for Regenerative Medicine in 2006, was able to tease apart muscle and urothelial cells from a bladder biopsy and then regrow both for the inner and outer surfaces of a reconstituted bladder on a scaffold of collagen and polyglycolic acid. From biopsy to implanting the new bladder took seven weeks. He quickly followed that success with a similar procedure for five boys' urethras. Six years later, all five engineered urethras had held up and functioned naturally. Neither of these feats used any kind of stem cells, but Atala supposed that would be a direction for future work. ${ }^{46}$

\footnotetext{
${ }^{45}$ Paul Knoepfler, "Who really discovered stem cells: The history you need to know," The NICHE: Knoepfler Lab Stem Cell Blog, April 11, 2012, online, https://ipscell.com/2012/04/who-really-discoveredstem-cells-the-history-you-need-to-know/; Gianluca Sampogna, Salman Yousuf Guraya, and Antonello Forgione, "Regenerative medicine: Historical roots and potential strategies in modern medicine," Journal of Microscopy and Ultrastructure, 3:3 (September 2015): 101-107, online, https://www.sciencedirect.com/science/article/pii/ S2213879X1500053X This source lists the citations for Yamanaka's and Thomson's key publications.

${ }^{46}$ Anthony Atala, "Regenerative Medicine Strategies," Journal of Pediatric Surgery, 47:1 (January 2012): 17-28, online, https:// www.sciencedirect.com/science/article/pii/S0022346811008839; for recent developments in regenerative medicine, see these: a human acellular vessel, https://www.technologynetworks.com/ biopharma/news/an-off-the-shelf-replacement-for-damagedblood-vessels-319217?utm_campaign=NEWSLETTER_TN_ Biopharma\&utm_source=hs_email\&utm_medium=email\&utm content $=72834628 \& \_$hsenc=p2ANqtz-_PV2bKhCwbA-KOWsGH7bFyShkpHHWI30750ZMzhZQGvQFk1sBMcTqTbjZ3uuT54CaYJ8 avdNCWoFZTahTbYrG_5sGkMw\&_hsmi=72834628; stem cells to transplantable arteries, https://www.fiercebiotech.com/research/ growing-transplant-arteries-stem-cells?mkt_tok=eyJpljoiWIRJNU1tTTNaak0wTjJFMSIsInQiOiJLVktoOW1vczdwYTdmbXRRam Y0cTYwQkpKa1FrR2pTSmZ2VIRZMjU1dW1DRXk5YZIEZOZvWG1 qSkJrWmpTUDUyQnJTNkx5TIVjWU960FRkeGZYbWx2XC9WbFNqVE9ZeE5qdG4zRFJYNzV3YzNjSWdyQzhoQzk2eXZKdkZ5QzdCe
}

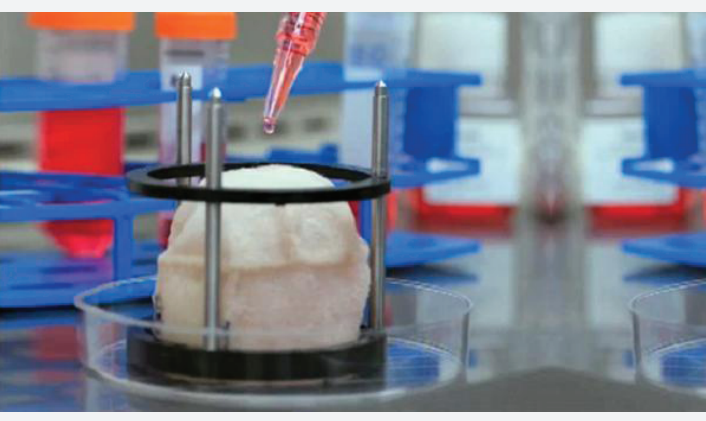

Figure 6. A form shapes regenerating a human bladder. Source: Wake Forest Institute for Regenerative Medicine.

Besides growing tissues on artificial scaffolds, researches are relying on 3D printing technology with bioinks containing living cells to make "hyperelastic bone," and transplantable heart and kidney organs. Neither tissue culture nor 3D printing are likely to make healthcare less expensive, but that too was the case with organ transplantation since its beginning in 1954. For those in need of a replaced kidney, heart or liver, regenerative medicine holds the possibility of escaping the need for long term immune suppression with an organ from a living donor or a cadaver. Minimally invasive approaches-for example, video assisted thoracic surgery which reduce hospital costs, may also make regeneration a cost effective choice for a longer healthy life (Fig. 6). ${ }^{47}$

British mathematician Alan Turing did not coin either term "artificial intelligence" or "machine learning," but his work in theorizing and building computers that could break the Nazi coded messages during World War II is the basis for the deserved claim that he is the father of artificial intelligence, and might also be considered the pioneer

HlifQ\%3D\%3D\&mrkid=983495; kidney cell repair, https://www. sciencedaily.com/releases/2019/03/190314123215.htm; artificial proximal tube, https://www.medgadget.com/2019/03/artificialproximal-tubule-model-mimics-functionality-of-real-kidneys.html; and regenerative medicine's gene editing toolbox, https://www.technologynetworks.com/genomics/news/expand-the-gene-editingtoolbox-scientists-sharpen-their-molecular-scissors-315822?utm_ campaign =NEWSLETTER_TN_Breaking $\% 20$ Science $\% 20$ News\&utm_source=hs_email\&utm_medium =email\&utm_content $=70208611 \&$ hsenc $=$ p2ANqtz-8P2vmDxhxuiOgMxu5TQ8kG8THbakyBpjCCaBdKjDcb81zFJe077FbuX0L99WsT03XYShemCKyGGAODOrgoU2La8s_e6g\&_hsmi=70208611

${ }^{47}$ Hyperelastic bone: https://www.the-scientist.com/news-opinion/ increasing-number-of-ips-cell-therapies-in-clinical-trials-65150; printing multivascular tissues: https://science.sciencemag.org/content/364/6439/458; first 3D printed heart with blood vessels: https:// www.rt.com/news/456590-worlds-first-3dprinted-vascular-heart/ 
of computational medicine. Turing may even have foreseen what was coming today.

Since Rontgen's first X-ray picture in 1895, imaging has guided diagnoses and therapies. Radiologists and pathologists each look at thousands of images or microscope slides over years of experience in developing their expertise. In-vitro fertilization involves scanning an embryo for distortions of size or texture before implantation. And multiple kinds of scopes show the state of tissue from the retina to the rectum. But medical people are not able to keep in their minds tens of thousands or hundreds of thousands of data points which a computer can do and use those patterns for new analyses. That's how artificial intelligence and machine learning work - from large study sets to "inform" a computer, reports show that machines produce higher accuracy than humans. In addition to pictures, artificial intelligence can interpret gene expression patterns, sounds from a "smart" statoscope, and very large data reports from wireless wearable (e.g. electronic "tattoos"), implantable (e.g. brain-computer interfaces), and ingestible ( e.g. camera pills) sensors. ${ }^{48}$

An audacious effort that could not have happened much earlier than now is the Human Microbiome Project. Its mission is to create a comprehensive "characterization" of the microorganisms that exist in the human body and their activity in sickness and health. They reside on the skin, in the nasal and ear passages, the mouth, the digestive tract and the urogenital tract. Individuals and their microbiome have a symbiotic relationship. People are their hosts, and the microbes have beneficial effects, as in producing vitamins that the human

\footnotetext{
${ }^{48}$ Al-assisted microscopy: https://www.the-scientist.com/features/ artificial-intelligence-sees-more-in-microscopy-than-humans-do65746?utm_campaign=TS_DAILY\%20NEWSLETTER_2019\&utm_ source=hs_email\&utm_medium =email \&utm_content $=72334065 \&$ hsenc $=$ p2ANqtz-ziOrY-E_QyBLymERKMnrPvPnVnRt7rpo-XMZm2skXEXtuiCjr4mQsQ020Kht1SE4B0gkCL-oFHU1bFYwWgp_dpVIOQQ\&_hsmi=72334065; Al-assisted IVF: https:// www.wired.com/story/ai-could-scan-ivf-embryos-to-help-makebabies-more-quickly/?utm_campaign=the_download.unpaid. engagement\&utm_source=hs_email\&utm_medium=email\&utm content $=71485114 \&$ hsenc $=$ p2ANqtz-8pXqdkQ_h1C4kVRu1KL1dSn2ISX4FwBuWLyxS6h_0KgM2d7w4wQsZD7G3S7i6CxI4KkgGKI6szH7SGe_alaYVEXpdVLQ\&_hsmi=71485114; Al analysis of breast cancer slides has superior accuracy than pathologists: https://www.sciencedaily.com/releases/2016/06/160620085204. htm; Al-assisted auscultation: https://www.fiercebiotech.com/ medtech/fda-clears-first-ai-powered-mobile-app-to-catch-heartmurmurs?mkt_tok=eyJpljoiWmpSak5tVTV0akkyTmp0aylsınQiOiJmNFIKdWYrTkRGNWRiajdraHB6am5wd2pNbWRpc1E4b0dFTkdkd2xidVF1U2pYWXAxNk10R25IdFIYRktcL2pGNmNYYWhVTzFZaHRoZmZqT1RWaTBmQ1wvVFIKeGk1cng4MIRQMnF3Y21DMm5ITTBtZ2UzQWVD0StaekNUdGJ0V1ZcLyJ9\&mrkid=983495;
}

genome cannot. Altogether, the human microbiome amounts to some one hundred trillion organisms - mostly bacteria, weighing altogether from two to six pounds depending on the person's size. A microbiome can have 200 times more DNA than a human genome, and these microorganisms effect the expression of human genes. Taking samples from some 300 people, the researchers (at several institutions) are examining how microorganisms figure in pregnancy and premature birth, how inflammatory bowel disease begins, and what causes Type 2 diabetes. To carry out those studies, they will, first, have to culture the organisms outside the body, many of which have never been isolated before; then sequence each species, and investigate how they evolve on or in a person's body. Like each human genome, each human microbiome is unique. The key technology for all of this is artificial intelligence to handle the almost unimaginable complexity of data. ${ }^{49}$

If behaviors account for $40 \%$ of the factors leading to premature death - behaviors like diet and exercise - the Human Microbiome Project may have as great a potential for improving health expectancy as anything else. Early in the $20^{\text {th }}$ century, Russian zoologist Elie Metchnikoff proposed that life could be extended and health improved, if people ate fermented milk (e.g. yogurt) because the lactic acid supported certain white blood cells (macrophages) in clearing harmful proteins from the body. For his discovery of macrophages he shared the 1908 Nobel Prize. He titled his 1910 book, The Prolongation of Life. Dannon Yogurt picked up this idea in 1977 with television ads featuring Soviet Georgia centenarians, but enthusiasm for this dietary advice rose and fell. However, microbiome scientists may have found the link between the gut, brain, and aging. Enteroendocrine cells, which spatially populate the gastrointestinal tract secrete serotonin, hormones and other chemicals that switch

\footnotetext{
${ }^{49}$ National Institutes of Health, Office of Strategic Coordination-The Common Fund, "The Human Microbiome Project," online: https:// commonfund.nih.gov/hmp/overview; Paul Hunter, "We are what we eat. The link between diet, evolution in genetic and non-genetic inheritance," EMBO Reports, 2008 May, 9 (5): 423-415, online, https:// www.embopress.org/doi/full/10.1038/embor.2008.61; Marcus Boehme, et al, "Mid-life microbiota crises: Middle age is associated with pervasive neuroimmune alterations that are reversed by targeting the gut microbiome," Nature Molecular Psychiatry, May 16, 2019, online, https://www.nature.com/articles/s41380-019-0425-1; M. K. Kenney and C.K. Ganta, "Autonomic Nervous System and Immune System Interactions," Comprehensive Physiology, July 2014, 4 (3): 1177-1200, online, https://www.ncbi.nlm.nih.gov/pmc/articles/PMC4374437/; Anna Peters, et al, "Metabolites of lactic acid bacteria present in fermented foods are highly potent agonists of human hydroxycarboxylic acid receptor 3," PLOS Genetics, May 23, 2019, 15 (5), online https://journals.plos.org/plosgenetics/ article?id=10.1371/journal.pgen. 1008145
} 
on and off neurotramsmitters. The autonomic vagus nerve, connecting the Gl track and the brain, transmits signals, and deterioration in that communication system from either the enteroendocrine cells, the vagus nerve itself, or synapses in the brain stem have harmful effects, particularly after age 50 when many physical and psychological changes set in. In the emerging field of "molecular psychiatry," one theory holds that "prebiotics" (substances that are consumed in food but are not digestible) such as inulin, trigger a bacterial response which, in turn, tamps down neuroendocrine signaling. This may explain why "grumpy old men" are grumpy, or why tremors stem from lost cells in the center of the brain in Parkinson's disease. Metchinkoff probably never knew of yogurt that was processed to reduce fat, but it exists today and in it, inulin fiber substitutes for fat. ${ }^{50}$

The complexity of the human microbiome, linking the gut to the brain, may ultimately require more supercomputing power than now exists on Earth. But just as few could have predicted the rise of artificial intelligence in bioanalytics only a short time ago, extending health expectancy may turn out to be a sudden unraveling of long ignored diet dynamics.

\footnotetext{
${ }^{50}$ Hayflick, How and Why We Age, p. 275; Alexandra L. Chang-Graham, et al, "Human Intestinal Enteriods with Inducible Neurogenin-3 Expression as a Novel Model of Gut Hormone Secretion," Cellular and Molecular Gastroenterology and Hepatology (in press, 2019), online, https://www.cmghjournal.org/article/S2352-345X(19)30049-9/ fulltext; Paul Hunter, "We are what we eat. The link between diet, evolution in genetic and non-genetic inheritance," EMBO Reports, 2008 May, 9 (5): 423-415, online, https://www.embopress.org/ doi/full/10.1038/embor.2008.61; Marcus Boehme, et al, "Mid-life microbiota crises: Middle age is associated with pervasive neuroimmune alterations that are reversed by targeting the gut microbiome," Nature Molecular Psychiatry, May 16, 2019, online, https:// www.nature.com/articles/s41380-019-0425-1; M. K. Kenney and C. K. Ganta, "Autonomic Nervous System and Immune System Interactions," Comprehensive Physiology, July 2014: 4 (3): 1177-1200, online, https://www.ncbi.nlm.nih.gov/pmc/articles/ PMC4374437/; Anna Peters, et al, "Metabolites of lactic acid bacteria present in fermented foods are highly potent agonists of human hydroxycarboxylic acid receptor 3," PLOS Genetics, May 23, 2019, 15 (5), online https://journals.plos.org/plosgenetics/ article?id=10.1371/journal.pgen.1008145; Rich Haridy, "Study shows how diet can prevent a mid-life microbiome crisis and improve brain health," New Atlas, May 23, 2019, online, https:// newatlas.com/gut-bacteria-microbiome-aging-brain-health-prebiotics/59809/; Sangjune Kim, et al, "Transneuronal Propagation of Pathologic $\alpha$-Synuclein from the Gut to the Brain Models Parkinson's disease," Neuron, June 26, 2019, online, https://www.cell. com/neuron/fulltext/S0896-6273(19)30488-X?_returnURL=https\% 3 A \%2F\%2Flinkinghub.elsevier.com\%2Fretrieve\%2Fpii\%2FS08966 2731930488 X\%3Fshowall\%3Dtrue
}

\section{Environmental factors}

The Centers for Disease Control and Prevention weighted environmental factors as the least influential causing premature death - only $5 \%$. But that may have changed since President Trump called "climate change" a Chinese hoax, downgraded the Environmental Protection Agency, and reversed pollution control regulations that government had put in place almost a half century ago. It remains to be seen if Trumposis is as short as a passing cold, or as long as the fourteen year Smallpox Eradication Campaign.

Outdoor and indoor air quality, surface and ground water quality, hazardous wastes, harmful building materials, and environmental monitoring all figure in a healthy environment. Good reasons exist to protect environmental health. In 1948 a choking smog hung over Donora, Pennsylvania; it harmed some 6,000 people in this steel-making town twenty miles south of Pittsburgh. Seventy died. Los Angeles suffered similar smog from temperature inversions, but the Smog Museum is in Donora. Most military bases, like Camp Lejeune, NC, have contaminated ground water from chemicals used to clean equipment and machinery, but the greatest single example of hazardous waste contamination is the story of "Love Canal" in Niagara Falls, NY. In 1978, news reports revealed the Hooker Chemical Company filled the abandoned canal with toxic chemicals, and then sold the property to the locality for $\$ 1$. Home builders developed the land, buyers suffered the consequences. Probably, some of the homes had particle boards in their construction that further exposed homeowners to formaldehyde contamination. Indeed, housing, and public housing in particular, has a long history of health negligence in its construction and maintenance. Perhaps the most extensive study of environmental hazards was that which Congress mandated in 1988 of the release of radioactive iodine from the Hanford, WA nuclear production facility, which had enriched plutonium for bomb production. Some 50,000 workers lived at the site, and thyroid cancer became an acute risk. A list of experiences like these would run to considerable length.

Perhaps the most encompassing environmental factor influencing life and health expectancy, short of a massive nuclear war, is climate change. The simple theory of this is that burning fossil fuels releases carbon dioxide into the atmosphere which creates a greenhouse effect. From ice core samples, researchers suppose the level of $\mathrm{CO}_{2}$ during the last ice age was 200 parts per million; it rose to $350 \mathrm{ppm}$ by 1993, and passed 415 ppm in 2019. Other gasses contribute to global warming, but $\mathrm{CO}_{2}$ is the Earth's heating blanket. A group of more than 70 medical and public health organizations - including the American Medical Association, the American College of Physicians, and the American Academy 
of Pediatrics - in June 2019 called climate change "a true public health emergency." ${ }^{51}$

Warming is the first part; population growth is the second. World population growth has been slowing since 1960, but there are now 7.7 billion people on the planet (2019), and demographers project there will be 11 billion by 2055. By and large the human family has seen health improvements over the past half century, and while there is no guarantee health and life expectancy will continue to tick up, there is a chance it will. The US population is projected to rise from 334 million today to 400 million by 2058. 2030 may be an important threshold, when people older than 65 will outnumber children for the first time in the nation's history. As this population increases with fewer births and longer lives, the human genome tends to become a stabile target for emerging diseases. Every birth is a new problem for a pathogen as it tries to make its way through as many hosts as possible. ${ }^{52}$

The third part, then, is emerging diseases that have rarely or never plagued the world before. Climate change alters a pathogen's "traffic pattern," a term Rockefeller University epidemiologist Stephen S. Morse coined. Some pathogens die out, others rise from obscurity. Global warming could bring increased crop yields, but that would support a rise in rodents. Machupo and Junin hemorrhagic fevers both emerged in South America (Bolivia and Argentina respectively) as their causative viruses became more virulent in passing through more rodents, before jumping to humans. In those cases, vaccines eventually arrested the outbreaks. Known viruses, bacteria and molds have come and gone in past epidemics, but it is unlikely researchers have discovered every pathogen that presents a human health hazard.

\footnotetext{
${ }^{51}$ Thomas E. Lovejoy, "Global Change and Epidemiology: Nasty Synergies," in Stephen S. Morse, Emerging Viruses (New York: Oxford University Press, 1993), p. 263; Peter Dockrill, "It's Official: Atmospheric $\mathrm{CO}_{2}$ Just Exceeded $415 \mathrm{ppm}$ For the First Time in Human History, Science Alert, May 13, 2019, online, https://www. sciencealert.com/it-s-official-atmospheric-co2-just-exceeded415-ppm-for-first-time-in-human-history; Joanne Finnegan, "Medical groups call climate change a 'health emergency,' FierceHealthcare, June 25, 2019, online, https://www.fiercehealthcare.com/ practices/medical-groups-call-climate-change-a-health-emergency

${ }^{52}$ Worldometers, Current World Population, online, https://www. worldometers.info/world-population/ Julie Iriondo and Jewel Jordan, Public Information Office, US Census, "Older People Projected to Outnumber Children for First Time in U.S. History, U.S. Census Newsroom, September 6, 2018, online, https://www.census.gov/ newsroom/press-releases/2018/cb18-41-population-projections. html; "Population projections for the United States from 2015 to 2060 (in millions)," Statista, online, https://www.statista.com/statistics/183481/united-states-population-projection/
}

Indeed, scientists at Ohio State University recently identified 195,728 previously unknown viruses brought up from the ocean's floor. And, news of molds that are highly resistant to radiation 200 times greater than a lethal human dose have appeared on a panel where exercise clothes were put out to dry in the International Space Station. These molds, of Apergillus and Pennicillium, did not come from space, but were brought from Earth to an environment that models the greenhouse effect. Science fiction writers and movie makers realize the dramatic value unknown pathogens have scaring people for entertainment, but they really are no match for the real thing. ${ }^{53}$

To sum up the potential for extending health expectancy, two processes are involved: one biological, the other historical. Biologically, a limit to life and health exists, though most people never reach an ultimate "stop" point, which is governed by a finite number of cell divisions. Conceivably, a new class of drugs, called "senolytics," may slow cellular senescence, and the first clinical trial of two of these drugs, dasatinib and quercetin, is now under way, for treating idiopathic pulmonary fibrosis. Regenerative medicine could lead to replacing worn out body parts. But in either case, humans won't be able to live past 125 years. If they could, reproduction would have to virtually cease, allowing an opportunistic pathogen a "target rich" environment. Simply, the price of immortality would be extinction. Short of that, however, average life expectancy could rise to near 100 , and average health expectancy into the 90s. Dying as one wishes might become the other end of the spectrum that begins at birth, with the

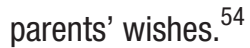

The historical process aims to inform the present about the future with perspective from the past. Extended life and good health really have a 200 year window, from 1900 to

\footnotetext{
${ }^{53}$ Stephen S. Morse, "Examining the Origins of Emerging Viruses," Ch. 2 in Morse, ed., Emerging Viruses; "Ohio State University Scientists Discovery Nearly 200,000 Unknown Viruses in Ocean Depths; Could Lead to Biotechnology Breakthroughs," Dark Daily, July 1, 2019, online, https://www.darkdaily.com/ohio-state-universityscientists-discover-nearly-200000-unknown-viruses-in-oceandepths-could-lead-to-biotechnology-breakthroughs/ ; David Szondy, "ISS is how to super-tough molds that laugh in the face of deadly radiation," New Atlas, June 28, 2019, online, https://newatlas.com/ iss-mold-radiation/60343/

${ }^{54}$ Jamie N. Justice, et al, "Senolytics in idiopathic pulmonary fibrosis: Results from a first-in-human, open-label, pilot study," EBioMedicine, 2019, online, https://www.ebiomedicine.com/article/S23523964(18)30629-7/fulltext; Rina Raphael, "I refuse to have a terrible death; the rise of the death wellness movement, "Fast Company, May 17, 2019, online, https://www.fastcompany.com/90337388/irefuse-to-have-a-terrible-death-the-rise-of-the-death-wellnessmovement
} 
2100 , not just year to year or Census to Census variations. Predicting and preventing hypertension among adults, controlling obesity in children, and averting suicide and addiction in young adults would go a long way toward building a great society's health culture. Bringing about this change depends on actions at the personal level and in national policy. That future history could read something like the opening line of Dickens' "David Copperfield: Whether I shall turn out to be the hero of my own life, or whether that station will be held by anybody else, these pages must show." 55

${ }^{55}$ Charles Dickens, A Personal History of David Copperfield (London: Bradbury \& Evans, 1850), p. 1 Interestingly, a fine, first edition of this book (https://www.biblio.com/book/personal-history-david-copperfield-dickens-charles/d/910484096) costs only about $\$ 900$ less than a diabetic's year supply of insulin, due to the reprehensible increase in the drug's price. 